\title{
Tools of the trade: trade flexibility with respect to margins and buyers
}

\author{
Frank Asche $e^{1,2} \cdot$ Atle Oglend ${ }^{2} \cdot$ Hans-Martin Straume ${ }^{3}$ (D) \\ Received: 25 July 2019 / Accepted: 31 July 2020 / Published online: 12 August 2020 \\ (C) The Author(s) 2020
}

\begin{abstract}
Access to highly disaggregated trade data allows for a more nuanced investigation of different margins of trade, and the factors known to influence them. In this paper, the number of importers and shipments to each importer is investigated together with the more traditional margins. Potential explanatory factors of these trade margins are combined from three literature strands in addition to the standard gravity variables; firm productivity, per-unit shipment costs and country-specific trade costs. The empirical results show, not unexpectedly, that insights from all these different strands of literature influence trade margins significantly. In particular, the number of shipments per importer increases with distance, degree of remoteness and per-shipment cost, and the number of importers decreases with the distance, remoteness and per-unit shipping cost. This indicates that increased trade costs make exporters economize in existing networks. Finally, disaggregating the data into three main product categories using Rauch's classification, trade patterns are shown to vary by product group.
\end{abstract}

Keywords Trade costs $\cdot$ Exporting $\cdot$ Margins of trade $\cdot$ Transaction data Heterogeneous firms

JEL Classification F10 $\cdot$ F14 $\cdot$ L11

Electronic supplementary material The online version of this article (https://doi.org/10.1007/s00181-02 0-01923-2) contains supplementary material, which is available to authorized users.

$\triangle$ Hans-Martin Straume

hans-martin.straume@bi.no

1 Institute for Sustainable Food Systems and School of Forestry Resources and Conservation, University of Florida, Gainesville, USA

2 Department of Industrial Economics, University of Stavanger, Stavanger, Norway

3 Department of Economics, BI Norwegian Business School, Bergen, Norway 


\section{Introduction}

Countries do not trade, firms trade (Hallak and Levinsohn 2004). Aggregate trade flows are determined by the decisions of a number of individual firms with respect to how they organize their activities at the export as well as import side. Few firms export, and those who engage in exporting activities typically sell a few products to a limited number of markets (Bernard et al. 2007; Mayer and Ottaviano 2008; Bernard et al. 2012). There is a rapidly expanding literature on the role of heterogeneous firms in the trade literature. Due to data availability, most studies focus on exporter (seller) heterogeneity, and few studies accounts for the role of individual importers (buyers). While many researchers have access to firm-level data at the exporter-product-destination country level, few datasets exist for the exporting-importing-product-destination country level. In this paper, we have access to a unique exporter-importer-product-destination country-level data for all mainland Norwegian exports, which will be used to investigate two main objectives. First, using the unique characteristics of the data we are able to propose the number of buyers and the mean number of shipments per importer per product as new parts of the exporters' extensive margin of trade. Second, we bring together independent variables from different strands of the trade literature to investigate the effect on the extensive and intensive margin of trade.

Melitz (2003) shows that trade costs can vary between firms and markets and contain fixed, as well as variable components, influencing which firms export to any specific market. This is the main foundation of several literature strands as more microdata have become available to empirically investigate trade dynamics at the firm level. ${ }^{1}$ These include the importance of firm productivity (Bernard et al. 2007), margins of trade (Bernard et al. 2009; Lawless 2010), networks (Rauch 1999; Rauch and Trindade 2002; Chaney 2014; Bernard et al. 2018; Bernard and Moxnes 2018) and various types of firm and destination-specific trade costs (Lawless 2010; Hornok and Koren 2015). In addition, Bernard et al. (2011) and Hornok and Koren (2015) show how the traditional extensive and intensive margins of trade can be nuanced when more detailed data are available, as they depend on factors such as the number of exporting firms and shipments.

Bernard et al. (1995) and Bernard et al. (2007, 2009) establish several empirical regularities for US exporters firms: relatively few firms engage in international trade, exporters are large, large exporters ship the highest number of products, exporters pay higher wages, employs the most skilled workers and are most productive. Mayer and Ottaviano (2008) report similar results for European firms. Feenstra and Romalis (2014) show that quality and price increase with firm size, and that smaller markets tend to be served by fewer firms supplying higher quality. These results suggest that export firm characteristics can be important factors in determining trade flows, and the impact may vary along different trade margins.

As more disaggregated data have become available over time, several different measures of trade cost have also received attention in addition to the traditional gravity variables of geographical distance and GDP. Lawless (2010) nuances the effect of

\footnotetext{
$\overline{1}$ Bernard et al. (2012) stresses better access to microdata as a success criterion for investigating firm heterogeneity.
} 
the distance measure of trade cost by also introducing country size and degree of urbanization to cover internal trade costs in a country. Hornok and Koren (2015) moves even closer to the model of Melitz (2003) by accounting for explicit trade cost measures in various countries such as time- and monetary costs of export as proxies for per-shipment cost. These different measures account for various aspects of trade frictions, which suggests that all should be present and relevant in a complete empirical analysis of trade patterns.

To our knowledge, no papers combine the explanatory factors from the different strands of the literature into one empirical framework. In this paper, access to highly detailed microdata allows us to do so. In addition to gravity variables, the paper evaluates the role of firm productivity, per-unit shipment costs and country-specific trade costs on trade margins. The margins of trade we consider are (1) mean number of shipments per importer per product, (2) number of importers, (3) number of products, (4) mean shipment weight and (5) mean unit trade value. The empirical analysis is carried out for all non-oil exports from Norway in the period 2004-2013. ${ }^{2}$

Results using the disaggregated trade data show that it is the most productive exporters that connect to the highest number of buyers. Furthermore, increased distance to the destination market chokes off trade, and we document that the importer margin accounts for the largest part of this negative relationship. As distance to the destination market increases, exporters reduce the size of their buyer network and trades more frequently in established networks. We also document that as per-unit shipment cost increases, aggregate trade decreases, with the importer margin accounting for a large part of this negative effect. We also divide the trade data into differentiated goods, reference priced goods and goods traded on organized exchanges based on the classification of Rauch (1999). Not, surprisingly, trade margins differ significantly by product group. In particular, Rauch's (1999) argument that the negative distance effect is stronger for reference priced goods than for the two other groups is supported. The overall results in this paper highlight the importance of the extensive margin in explaining cross-sectional differences in trade due to both the traditional gravity effects and trade costs.

The paper is organized as follows. In the next section, we provide an overview over the relevant literature, Sect. 3 offers a discussion on the decomposition of the margins of trade. In Sect. 4, the data and the empirical approach are presented. Section 5 discusses trade costs and trade margins, while Sect. 6 studies how different product characteristics affect trade margins. The final section concludes.

\section{Literature review}

The literature on trade margins using firm-level data begins with Eaton et al. (2004) who argues that aggregate exports to a given destination market are made up by the number of firms selling in that destination times the average sale per firm in the destination. The first term is what is commonly referred to in the literature as the extensive margin of trade, the latter being the intensive margin. Eaton et al. (2004) use

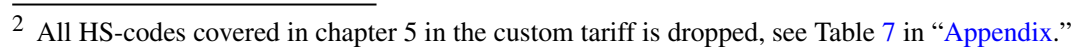


French firm-level data to show that few firms export, few exporters serves multiple markets and that the number of firms serving a given market increases with market size.

Bernard et al. (2007) studies margins of trade using US export data. They decompose aggregate export value to a destination into three elements; the number of firms exporting to a given destination, the number of products exported to the destination and the average value of export per firm per product. A gravity-type equation is estimated on aggregate exports, as well as for each of the three margins. Bernard et al. (2007) include the geographical distance to the destination market and the GDP of the destination as covariates. Their findings show that aggregate export value, the number of exporters and the number of products increases with GDP and decreases with distance. The results are a bit more puzzling for the intensive margin where they find the opposite effects from the two covariates. A possible explanation for this finding is that the composition of exports changes toward trade in higher-value commodities when the distance to the destination market increases.

Building on Eaton et al. (2004) and Hillberry and Hummels (2008) suggests decomposing trade at the firm-product-destination level as the product of the number of products, the average number of shipments between a firm and a destination and the average value per-shipment. Using data for manufacturers' shipments within the US, they find that distance between regions and other trade frictions has a negative effect on trade values. Fewer commodities being shipped and fewer firms shipping as frictions increases cause this.

Lawless (2010) expands the empirical analysis in Bernard et al. (2007) by adding several trade costs in the model and also decompose aggregate US exports into the same margins as Eaton et al. (2004). Geographical distance have a negative impact on both the extensive and intensive margin, with the strongest effect on the extensive margin. Additional proxies for trade costs such as per-unit shipment costs measured as time-and-monetary costs of clearing customs has a negative impact on trade value and primarily works through the extensive margin. There is little evidence for any significant effect from these additional trade costs on the intensive margin of trade.

Bernard et al. (2011) develops a general equilibrium model of multiple-product, multiple-destination firms that allows for heterogeneity in ability across firms, and in product attributes within firms. One of the predictions of the model is related to trade margins, as it suggests that higher variable trade costs reduce the number of exporting firms and the average number of products exported by each exporter. The model has no clear prediction for how increased variable trade costs impact the intensive margin of trade.

Bernard et al. (2014) studied the effect from firm productivity of Belgian multiproduct exporters on aggregate exports and different margins of trade. They find a positive effect from productivity on exports across firms. The usual exporter characteristics are established for the Belgian exporters, there are a few dominant firms that accounts for a large share of aggregate exports, and the most productive firms sell more products in more destination markets. The effect from gravity variables (distance and GDP) is investigated, and the results are in line with previous findings in the literature. There is a positive effect from GDP, and an negative distance effect, on aggregate exports, as well as for the number of firms that exports and the number 
of products exported. The effect from the gravity variables on the intensive margin is more ambiguous.

Hornok and Koren (2015) show that increased per-shipment costs are associated with less frequent and larger shipments in international trade. They use export data for the US and Spain and estimate gravity-like regressions on the different margins. One important finding is that increased per-unit shipment costs are most disruptive for trade in perishable products. As covariates for total exports and the different margins covariates such as distance, GDP in the destination market, time costs of exporting and monetary costs of exporting are included. The findings suggest that increased distance has a negative impact on aggregate export value and the number of shipments while there exists a positive effect on shipment values. Increased GDP increases export values, the number of shipments and the shipment values. Increased per-unit shipment costs decreases the number of shipments and increases shipment value.

Arkolakis et al. (2008) is the first to emphasize the importance of the number of buyers for aggregate exports. The paper provides a model where firms reach individual customers rather than a given destination market. The higher costs the firm (exporter) pay, the more customers can be reached within a destination market. Using the USMexico NAFTA liberalization period, it is shown that increased aggregate exports can be traced back to an increase in the number of exporters, and more importantly, to an increase in the number of customers (buyers).

Importer-exporter relations between Chinese exporters and US importers are discussed in Monarch (2014) who studies how costs from switching suppliers can affect prices by discouraging importers to move from high- to low-cost exporters. Approximately $50 \%$ of importers keep their partners, and about one-third of importers that switches exporter stays within the same city. Switching in importer-exporter relations becomes less frequent with lower prices and higher quality.

Bernard et al. (2018) uses Norwegian transaction data similar to the data used in this paper to develop a model that provides a microfoundation for exporter-importer relationships in trade. The paper establishes the buyer dimension as a margin of trade and document a set of facts on the heterogeneity of buyers and sellers and their relationships. The buyer margin is an important part of the extensive margin of trade as it explains a large share of the variation in aggregate exports. Within a market, exporters with many buyers have a larger share of the market. The better connected an exporter is, the less well connected is its average importer (negative degree assortativity).

Carballo et al. (2018) employs transaction-level data for exporters from three different South-American countries and their importers to investigate the presence and characteristics of dominant importers. Multi-buyer exporters are important for aggregate exports and trades with a few dominant buyers. The relative importance of dominant buyers varies across destination according to the toughness of competition determined by the size and accessibility of the market. Buyer shares of exports increase in the GDP of the destination market and decrease in distance between the trading partners.

Besedeš and Prusa (2011) argue that countries could improve aggregate export growth if more attention was paid to the survival of trade relationships, as increased survival would expand the intensive margin of trade. Duration of trade between exporters and importers is more recently studied by Geishecker et al. (2019). Using Danish 
transaction-level data for manufacturing firms, they find that one-off exports (trading takes place only one time over a 49-month window) are the dominant spell length at the firm-product-destination level. Low productivity firms that are economically small dominate one-off exports and the presence of such trade relationships increases with the geographical distance to the destination market and with trade toward lowincome destination markets. A potential explanation for one-off exports could be passive exporting meaning that a foreign importer contacts the exporter, who does not initially seek to export, and a one-off transaction takes place.

There exist a rich empirical literature on export performance at the firm level that is grounded in heterogeneous-firm models building on the framework of Melitz (2003) and Mayer and Ottaviano (2008). This literature does not estimate gravity-models in the traditional way, but include gravity-like regressors such as distance, GDP in the destination country and remoteness, to study the variation in export performance at the firm level. E.g., Görg et al. (2017), Manova and Zhang (2012) and Johnson (2012) have studied the differences in export prices across firms and argue that exporters charge higher prices in richer and more distant markets. Such positive gradient between distance and FOB export prices is not necessarily in line with theoretical models (e.g., Melitz (2003) and Melitz and Ottaviano (2008)) and may be dependent on the level of aggregation. The empirical part of this paper aligns better to this literature, than to the standard gravity literature.

\section{Margins of trade}

Traditionally, trade has been decomposed along two margins; the extensive margin (the number of firms exporting or importing), and the intensive margin (increased exports or imports at the firm level). These traditional margins can be further nuanced when more detailed data are available. Regressing these margins on a set of trade determinants then allows a useful empirical analysis to ascertain how proposed trade determinants influence different margins of trade.

Bernard et al. (2011) and Hornok and Koren (2015) provide empirical estimates of different sets of trade margins at the country level. ${ }^{3}$ Bernard et al. (2011) focus on the impact of gravity variables on a set of trade margins at the country level, while Hornok and Koren (2015) use gravity variables and per-shipment unit costs as additional measures of trade costs.

Bernard et al. (2011) shows that the total value of exports to a destination market, $X_{c}$, can be written as:

$$
X_{c}=F_{c} * J_{c} * d_{c} * \bar{V}_{c},
$$

where $F_{c}$ is the number of firms that exports to destination $c, J_{c}$ is the number of products exported, $d_{c}$ is a density term that captures the extent to which each firm supplies each product and $\bar{V}_{c}$ is the average value exported. Bernard et al. (2011)

\footnotetext{
3 Bernard et al. (2011) also utilize firm-level data.
} 
regress each of these margins as well as the total export value on the gravity variables distance and GDP in the destination country.

Going further, Hornok and Koren (2015) describe the total value of exports of a given product $g$, to a given destination $c$, using transportation mode $m$ as:

$$
X_{c, g, m}=H_{c, g, m} * N_{H, c, g, m} * \bar{P}_{c, g, m} * \bar{Q}_{c, g, m}
$$

where $H_{c, g, m}$ is the number of months in a given year with positive trade, $N_{H, c, g, m}$ is the average number of shipments in each month with positive trade, $\bar{P}_{c, g, m}$ is the average unit value (price) and $\bar{Q}_{c, g, m}$ is the average shipments size. Hornok and Koren (2015) regress the gravity variables from Bernard et al. (2011) and per-shipments costs on each of the margins in (2).

Access to information about the importing firm in each transaction influences how the margins can be decomposed. The number of trade partners in a country is important as the total number of shipments to a destination can be increased both by having more shipments to existing partners and starting to ship to new partners. As such, we propose the following trade value decomposition at the exporter level, whereby firm $i$ 's export value to destination country $c$ in year $t$ is decomposed as:

$$
X_{i, c, t}=\bar{N}_{i, c, t} * I_{i, c, t} * J_{i, c, t} * \bar{Q}_{i, c, t} * \bar{P}_{i, c, t},
$$

where $\bar{N}$ is the average number of shipments per trading partner (importing firm) per product, $I$ is the number of trading partners and $J$ is the number of traded products. Average shipment size, $\bar{Q}_{i, c, t}$, and average unit value, $\bar{P}_{i, c, t}$, are as in (2).

This decomposition offers $\bar{N}_{i, c, t}$ and $I_{i, c, t}$ as new margins of trade. The extensive margin then consists of the number of importers a firm trades with, as well as the number of shipments and the number of products it ships to them. We investigate empirically the joint role of trade determinants on the margins in (3).

\section{Data}

The data used in this paper are Norwegian transaction-level customs data for the period 2005-2013. The data cover the whole universe of non-oil and mineral products in Norwegian exports at the most detailed HS-level possible. For each transaction, the exporter and the importer are identified by a specific id-code. Moreover, each observation contains information on the free-on-board (fob) value in Norwegian kroner (NOK), the destination country and the export date. The structure of the transaction data makes it possible to aggregate the firms trading activities into yearly frequencies. In addition to the transaction data, we have access to the Norwegian firm's financial accounts. This means that we, at the firm level, can merge the trade data with information on the firms' sales and the number of employees. This feature of the data is used to measure firm-level productivity. 
The total export value for the period sums up to approximately 2027 billion NOK. ${ }^{4}$ Over the period, Norwegian exporters' trades in 6109 distinct HS-codes. ${ }^{5}$ In total, 24,107 Norwegian firms' exports to 401,560 foreign importing firms in 192 different destination countries. The yearly number of exporters varies between 9524 (2008) and 8754 (2009), and the corresponding numbers for importers are from 68,877 (2005) to 76,397 (2013). All trades can be categorized in one of the different product groups described in the Norwegian customs tariff. ${ }^{6}$ Transactions with a value below 10,000 NOK (approx. 1250 USD) are excluded, and to get a consistent unit measure only shipments denoted in kilos are included.

To get a picture of the data, Table 1 reports the number of exporters, importers, destination countries and HS-codes found in the 21 different main product groups in the Norwegian custom tariff, ranked on trade value.

The largest number of exporting firms operates in the category "Machinery and mechanical appliances," with a total number of 13,346 firms. The lowest number of firms is found in the product group "Arms and ammunition." As the product groups are ranked by total export value, the exporting firms in the group "Live animals; animal products" (833) are suspected to be large. The largest number of importers is found in the product group "Machinery and mechanical appliances" with a number of 189,509 firms. We find the largest number of distinct HS-codes and destination countries in the product category "Machinery and mechanical appliances." The product category with the lowest number of HS-codes is "Works of art."

\section{Empirical analysis of trade margins}

The empirical analysis investigates how the margins specified in Eq. (3), $\bar{N}_{i, c, t}, I_{i, c, t}, J_{i, c, t}, \bar{Q}_{i, c, t}$, and $\bar{P}_{i, c, t}$, are affected by a set of explanatory variables. These include the traditional gravity variables as well as variables that have been shown to be important in various strands of the firm-oriented international trade literature. Each regression takes the following form:

$$
\begin{aligned}
\operatorname{lnMargin}_{i, d, t}= & \alpha_{i}+\boldsymbol{\beta} \operatorname{lngravity}_{d, t}+\boldsymbol{\omega} \operatorname{lntradecost}_{d, t} \\
& +\boldsymbol{\gamma} \operatorname{lnfirm}_{i, d, t}+\vartheta_{\boldsymbol{i}}+\boldsymbol{\sigma}_{t}+\varepsilon_{i, d, t}
\end{aligned}
$$

The sum of all margin coefficients in (4) adds up to the total effect of determinants on the firms export value, $X_{i, c, t}$. In Eq. (4), the vector gravity $_{d, t}$ represents explanatory variables used in the traditional gravity literature. These are geographical distance from Norway to the destination market as a proxy for transportation costs and GDP in the

\footnotetext{
4 Using an average annual exchange rate of 6.1 NOK/USD, the corresponding number in USD gives an export value of 332 billion.

5 From 2012, several products changed HS-codes after the HS-nomenclature was updated. A correspondence table is given by UN Trade Statistics at https:/unstats.un.org/unsd/trade/classifications/ correspondence-tables.asp.

6 A comprehensive list of the 21 different product groups used at the CN1-level in the Norwegian Custom Tariff is provided in Table 7 in "Appendix."
} 
Table 1 Number of exporters, importers, destination countries, HS-codes and total export value

\begin{tabular}{|c|c|c|c|c|c|}
\hline Product group & \# Exporters & \# Importers & $\begin{array}{l}\text { \# Destination } \\
\text { countries }\end{array}$ & \# HS-codes & $\begin{array}{l}\text { Total export value } \\
\text { (billion NOK) }\end{array}$ \\
\hline 15. Base metals & 7465 & 57,729 & 179 & 661 & 525 \\
\hline $\begin{array}{l}\text { 1. Live animals; } \\
\text { animal products }\end{array}$ & 833 & 26,220 & 146 & 547 & 409 \\
\hline $\begin{array}{l}\text { 16. Machinery } \\
\text { and mechanical } \\
\text { appliances }\end{array}$ & 13,346 & 189,504 & 191 & 1135 & 354 \\
\hline $\begin{array}{l}\text { 6. Products of the } \\
\text { chemical or } \\
\text { allied industries }\end{array}$ & 2921 & 29,914 & 167 & 738 & 318 \\
\hline $\begin{array}{l}\text { 7. Plastic and } \\
\text { rubber products }\end{array}$ & 5065 & 40,212 & 167 & 287 & 76 \\
\hline $\begin{array}{l}\text { 17. Transport } \\
\text { products }\end{array}$ & 5311 & 18,926 & 156 & 199 & 70 \\
\hline $\begin{array}{l}\text { 10. Paper and } \\
\text { paper products }\end{array}$ & 3007 & 17,977 & 152 & 163 & 68 \\
\hline $\begin{array}{l}\text { 18. Instruments } \\
\text { (e.g., precision } \\
\text { and optical) }\end{array}$ & 4777 & 48,940 & 174 & 260 & 60 \\
\hline 20. Miscellaneous & 4020 & 18,960 & 156 & 157 & 29 \\
\hline $\begin{array}{l}\text { 4. Prepared } \\
\text { foodstuffs and } \\
\text { beverages }\end{array}$ & 1022 & 6898 & 129 & 351 & 27 \\
\hline $\begin{array}{l}\text { 14. Precious } \\
\text { metals }\end{array}$ & 388 & 1254 & 60 & 38 & 20 \\
\hline $\begin{array}{l}\text { 19. Arms and } \\
\text { ammunition }\end{array}$ & 94 & 1121 & 54 & 27 & 20 \\
\hline $\begin{array}{l}\text { 13. Articles of } \\
\text { stone, plaster, } \\
\text { cement, etc. }\end{array}$ & 2058 & 9254 & 118 & 175 & 15 \\
\hline $\begin{array}{l}\text { 3. Animal or } \\
\text { vegetable fats } \\
\text { and oils }\end{array}$ & 227 & 2033 & 72 & 78 & 14 \\
\hline $\begin{array}{l}\text { 11. Textiles and } \\
\text { textile articles }\end{array}$ & 2922 & 14,300 & 149 & 656 & 9 \\
\hline $\begin{array}{l}\text { 9. Wood and } \\
\text { articles of wood }\end{array}$ & 1309 & 6231 & 100 & 153 & 6 \\
\hline $\begin{array}{l}\text { 8. Raw hides and } \\
\text { skins, etc. }\end{array}$ & 344 & 1765 & 65 & 64 & 5 \\
\hline $\begin{array}{l}\text { 2. Vegetable } \\
\text { products }\end{array}$ & 362 & 2633 & 75 & 379 & 2 \\
\hline $\begin{array}{l}\text { 12. Footwear, } \\
\text { headgear, etc. }\end{array}$ & 180 & 329 & 41 & 34 & 1 \\
\hline 21. Works of art & 176 & 909 & 44 & 7 & 1 \\
\hline Total & 24,107 & 401,560 & 192 & 6109 & 2027 \\
\hline
\end{tabular}

2005-2013. Groups ranked by export value (billion NOK) 
Table 2 Descriptive statistics and classification of explanatory variables

\begin{tabular}{llllll}
\hline Variable & Classification & Mean & SD & Min & Max \\
\hline Distance (1000 km) & Standard gravity & 2.23 & 2.89 & 0.41 & 17.99 \\
GDP (1,000,000,000 USD) & Standard gravity & 1595 & 2702 & 0.12 & 14,451 \\
Remoteness & Standard gravity & 2.75 & 1.24 & 0.46 & 5.61 \\
Monetary cost & Additional trade costs & 985 & 467 & 317 & 10,250 \\
Time cost & Additional trade costs & 9.61 & 6.94 & 4 & 117 \\
Size $(1000 \mathrm{~km})$ & Additional trade costs & 1458 & 3563 & 0.028 & 16,381 \\
Population $(1,000,000)$ & Additional trade costs & 48 & 93 & 0.01 & 721.7 \\
Productivity $(1,000,000)^{\mathrm{a}}$ & Firm-specific factor & 16.60 & 40.10 & 0.01 & 7032 \\
\hline
\end{tabular}

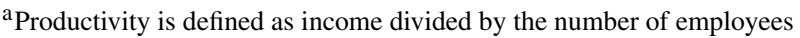

destination country to measure economic $\operatorname{size}^{7}$ of the destination market. A measure of remoteness, as suggested by Anderson and van Wincoop (2003), is also included in this vector. Remoteness is calculated as in Silva and Tenreyro (2006). The larger the value of the remoteness variable, the more isolated the country is relative to all other countries.

The vector trade costs $_{d, t}$ contains per-shipment costs (proxied by monetary and time costs) as suggested by Hornok and Koren (2015), and additional proxies for trade costs (country size and degree of urbanization) as suggested by Lawless (2010). The vector firm $_{i, d, t}$ contains a measure of firm productivity, sales divided by the number of employees. Finally, to control for time variation and unobserved firm-level effects, $\sigma_{t}$ and $\vartheta_{i}$ capture time and firm fixed effects, respectively.

Table 2 shows some descriptive statistics for all the explanatory variables used in the empirical analysis.

Table 3 reports the empirical results from the estimation of Eq. (4). All estimation results are reported with robust standard errors clustered by destination country.

In column (1) of Table 3, the results for total export value are presented. Note that the sum of row parameters from column two to six adds up to the column one parameters. The most important point to note is that not only are most parameters statistically significant, but there are significant parameters for all types of trade costs as well as for firm productivity. This indicates that accounting for the factors from all the different literature strands is important when investigating margins of trade, and that they separately contain independent information relevant to the margins. In particular, all regressors have significant and anticipated effects on the buyer margin.

\subsection{Firm export value}

We start by investigating the impact on firm export value. For the gravity variables, the estimated effect of distance and the remoteness of the destination country are mostly

\footnotetext{
7 Distance is taken from the CEPRII database and GDP, as well as additional trade costs, data from the World Bank Development Indicators. The data for the per-unit shipment costs are taken from the World Banks "Doing Business" survey.
} 
Table 3 Margin regressions, full data set

\begin{tabular}{|c|c|c|c|c|c|c|}
\hline & $\begin{array}{l}\text { (1) } \\
\text { Export value }\end{array}$ & $\begin{array}{l}(2) \\
\text { Mean \# } \\
\text { shipments } \\
\text { per } \\
\text { importer } \\
\text { per product }\end{array}$ & $\begin{array}{l}(3) \\
\# \text { of } \\
\text { importers }\end{array}$ & $\begin{array}{l}\text { (4) } \\
\text { \# products }\end{array}$ & $\begin{array}{l}(5) \\
\text { Mean } \\
\text { shipment } \\
\text { weight }\end{array}$ & $\begin{array}{l}(6) \\
\text { Mean unit } \\
\text { value }\end{array}$ \\
\hline Distance & $\begin{array}{l}-0.325^{* * *} \\
(0.010)\end{array}$ & $\begin{array}{l}0.055^{* * *} \\
(0.004)\end{array}$ & $\begin{array}{l}-0.226^{* * *} \\
(0.005)\end{array}$ & $\begin{array}{l}-0.179 * * * \\
(0.004)\end{array}$ & $\begin{array}{l}-0.142^{* * *} \\
(0.008)\end{array}$ & $\begin{array}{l}0.166 * * * \\
(0.005)\end{array}$ \\
\hline GDP & $\begin{array}{l}0.139 * * * \\
(0.011)\end{array}$ & $\begin{array}{l}-0.007 \\
(0.005)\end{array}$ & $\begin{array}{l}0.110 * * * \\
(0.005)\end{array}$ & $\begin{array}{l}0.057 * * * \\
(0.004)\end{array}$ & $\begin{array}{l}-0.087 * * * \\
(0.009)\end{array}$ & $\begin{array}{l}0.067 * * * \\
(0.006)\end{array}$ \\
\hline Remoteness & $\begin{array}{l}-0.290 * * * \\
(0.024)\end{array}$ & $\begin{array}{l}0.052 * * * \\
(0.010)\end{array}$ & $\begin{array}{l}-0.187 * * * \\
(0.011)\end{array}$ & $\begin{array}{l}-0.161 * * * \\
(0.009)\end{array}$ & $\begin{array}{l}-0.034^{*} \\
(0.019)\end{array}$ & $\begin{array}{l}0.037 * * * \\
(0.013)\end{array}$ \\
\hline $\begin{array}{l}\text { Monetary } \\
\text { cost }\end{array}$ & $\begin{array}{l}-0.142 * * * \\
(0.021)\end{array}$ & $\begin{array}{l}-0.013 \\
(0.008)\end{array}$ & $\begin{array}{l}-0.044 * * * \\
(0.009)\end{array}$ & $\begin{array}{l}-0.024 * * * \\
(0.008)\end{array}$ & $\begin{array}{l}-0.190 * * * \\
(0.017)\end{array}$ & $(0.010)$ \\
\hline Time cost & $\begin{array}{l}-0.375^{* * * *} \\
(0.018)\end{array}$ & $\begin{array}{l}0.087 * * * \\
(0.007)\end{array}$ & $\begin{array}{l}-0.229 * * * \\
(0.008)\end{array}$ & $\begin{array}{l}-0.220^{* * *} \\
(0.007)\end{array}$ & $\begin{array}{l}-0.036^{* *} \\
(0.014)\end{array}$ & $\begin{array}{l}0.023 * * \\
(0.009)\end{array}$ \\
\hline Size & $\begin{array}{l}-0.030 * * * \\
(0.007)\end{array}$ & $\begin{array}{l}0.018 * * * \\
(0.003)\end{array}$ & $\begin{array}{l}-0.026^{* * *} \\
(0.003)\end{array}$ & $\begin{array}{l}-0.015^{* * *} \\
(0.002)\end{array}$ & $\begin{array}{l}-0.004 \\
(0.005)\end{array}$ & $\begin{array}{l}-0.003 \\
(0.003)\end{array}$ \\
\hline Population & $\begin{array}{l}0.140 * * * \\
(0.012)\end{array}$ & $\begin{array}{l}-0.057 * * * \\
(0.005)\end{array}$ & $\begin{array}{l}0.050 * * * \\
(0.005)\end{array}$ & $\begin{array}{l}0.046 * * * \\
(0.004)\end{array}$ & $\begin{array}{l}0.182 * * * \\
(0.010)\end{array}$ & $\begin{array}{l}-0.082^{* * *} \\
(0.006)\end{array}$ \\
\hline $\begin{array}{l}\text { Firm pro- } \\
\text { ductivity }\end{array}$ & $(0.011)$ & $(0.004)$ & $(0.004)$ & $(0.004)$ & $(0.010)$ & $\begin{array}{l}-0.008 \\
(0.008)\end{array}$ \\
\hline Constant & $\begin{array}{l}8.128 * * * \\
(0.249)\end{array}$ & $\begin{array}{l}0.047 \\
(0.101)\end{array}$ & $\begin{array}{l}-0.731 * * * \\
(0.100)\end{array}$ & $\begin{array}{l}0.066 \\
(0.089)\end{array}$ & $\begin{array}{l}5.863 * * * \\
(0.216)\end{array}$ & $\begin{array}{l}2.900 * * * \\
(0.154)\end{array}$ \\
\hline Observations & 309,717 & 309,717 & 309,717 & 309,717 & 309,717 & 309,717 \\
\hline$R^{2}$ & 0.456 & 0.362 & 0.375 & 0.334 & 0.699 & 0.757 \\
\hline Time FE & Yes & Yes & Yes & Yes & Yes & Yes \\
\hline Firm FE & Yes & Yes & Yes & Yes & Yes & Yes \\
\hline
\end{tabular}

Robust standard errors clustered at the destination country in parentheses $* * * p<0.01 ; * * p<0.05 ; * p<0.10$

in line with common findings in the literature (Head and Mayer 2014). Export value decreases with geographical distance and degree of remoteness. The GDP variable indicates that export value increases with the economic size of the destination country. Increased shipment costs measured by the time to import and monetary cost of importing in the destination significantly reduce total export value significantly. Our findings for the two measures of per-unit shipment costs are as expected, increased costs chokes of export value. Hornok and Koren (2015) do not find a significant effect from time costs, but also finds that increased monetary costs decrease export value from the USA. Increased internal transportation costs, measured by internal geographic size, reduce export value, while increased urban population increases export 
value. These findings are in line with Lawless (2010). The export value is higher for more productive firms, as reported by Bernard et al. (2014).

\subsection{The extensive margin}

As the various margins add up to the impact on export value, the parameter estimates from column two to six show how the emphasis changes for the various margins. Columns two to four represent the extensive margins of trade in our decomposition. When interpreting the results from the different covariates on the margins of trade, it is important to recognize that, several results may be driven from how the firms self-select into both exporting as a activity, and trade to different destination markets.

For the number of shipments, the effect of distance and remoteness is positive, suggesting that remoteness and distance moderates the negative impact of these gravity variables on export value. Increased transportation costs as measured by distance increase the mean number of shipments per product to foreign importers. Firms may concentrate their export effort in a few markets due to well-established importer relationships, so this could be a indication of a network effect. Once an exporter finds a distant market attractive, it could invest heavily in a relationship and ship in large numbers.

The total effect of the two measures of per-shipment costs, monetary cost and time cost is that increased per-shipment costs increase the number of shipments per importer per product. The effect is driven by time costs. A similar effect is reported in Hornok and Koren (2015) for a combination of two procedural costs on the number of product-specific shipments to a destination market in a month. The mean number of shipments per importer per product increases with internal transportation costs (as measured by geographical size of market), and productivity and decreases with the degree of urban population.

Our data allow us to identify both the exporting firm and the importing firm. This makes it possible to isolate the number of importers in a destination market the exporter trades with as a distinct margin of trade. In line with the predictions of Bernard and Moxnes (2018), the number of importers (column 3) decreases with distance and increases with the economic size of the destination market (GDP), but the relationship with fewer importers appears to be deeper as the number of shipments increases. In addition, the number of importer connections increases as trade is directed toward less economically isolated markets. Also for increases in direct trade costs such as pershipment costs, the number of importers decreases. In fact, except for firm productivity, parameters on number of shipments to per importer and number of importers have opposite sign, suggesting that as number of importers decrease due to gravity or trade cost effect, the number of shipments per importer increase. This indicates that number of shipments per importer and number of importers work as substitute margins. The firm makes fewer connections in more distant high cost markets, but invests more heavily in each partner.

The effect from the additional trade costs, size and population on number of partners, is as anticipated. Firms establish fewer trade relations with importers in geographically large countries, but more with buyers in highly populated destinations. The effect on 
firm productivity on the number of importer connections is positive, indicating that it is the most productive exporters that connect to the highest number of foreign buyers. Productive firms are larger and so have lower average fixed costs of investing in new partners. In addition, saturation effects on existing partners will push larger firms to seek new partners.

The number of products exported (column 4) is a dimension of the extensive margin of trade exhaustively investigated, commencing with Bernard et al. (2007). Our results for the distance variable and GDP per capita are in line with the findings of Bernard et al. (2007). We also find that fewer products are being exported to the most remote markets. For the per-shipment costs, we find that both increased monetary costs, as well as increased time costs, result in export of fewer products. As internal transportation costs increase, the number of products exported decreases, while we find an increase in the number of products as population in the destination market increases. It is also the most productive firms in the Norwegian data that export the highest number of products.

\subsection{The intensive margin}

The two last margins in column 5 and 6 in Table 5 are the standard representations of the intensive margin of trade. When it comes to the average shipment weight, we find a negative correlation with distance and the degree of remoteness of the destination market, as well as with the per-unit shipment costs related to import in the destination. The largest shipments are not destined for the largest economies. The most productive firms export the largest quantities to highly populated destinations.

As Manova and Zhang (2012), we are able to document a positive and significant effect from increased distance on unit values. As Hornok and Koren (2015), we also observe the "Alchian-Allen"-effect (1964) from increased per-shipment costs on unit value. Further, we find that exports to economically large and remote markets also are associated with increased unit values. Trade to large urban areas has a negative effect on unit values, while productivity appears to relate primarily to firm size and not unit value.

As a robustness check, we follow the suggestion of Silva and Tenreyro (2006) and estimate the model using Poisson pseudo-maximum likelihood estimation to control for zeros in trade flows. Table 4 presents the results. As one can see, most of the covariates have the same sign and significance on total exports and the different margins as found in Table 3. However, there are some changes to note. The PPML estimation indicates that the covariates in the empirical model perform worse on the intensive margin. E.g., we see that the effect from remoteness and time costs reported in Table 3 disappears in Table 4. A main finding from the literature discussed in Sect. 2 is that in most papers investigating trade margins, e.g., Bernard et al. (2011), it is emphasized that the extensive margin outperforms the intensive margin, and that the findings from gravity-like regressors can be troublesome on the intensive margin. Our findings from the PPML estimation indicate that this is also the case for Norwegian firm-level exports. As a second robustness, we estimate the model with an alternative clustering 
Table 4 Margin regressions, full data set. PPML-estimates

\begin{tabular}{|c|c|c|c|c|c|c|}
\hline & $\begin{array}{l}(1) \\
\text { Export value }\end{array}$ & $\begin{array}{l}(2) \\
\text { Mean \# } \\
\text { shipments } \\
\text { per } \\
\text { importer } \\
\text { per product }\end{array}$ & $\begin{array}{l}(3) \\
\text { \# of } \\
\text { importers }\end{array}$ & $\begin{array}{l}\text { (4) } \\
\text { \# products }\end{array}$ & $\begin{array}{l}(5) \\
\text { Mean } \\
\text { shipment } \\
\text { weight }\end{array}$ & $\begin{array}{l}(6) \\
\text { Mean unit } \\
\text { value }\end{array}$ \\
\hline Distance & $\begin{array}{l}-0.027 * * * \\
(0.005)\end{array}$ & $\begin{array}{l}0.013 * * * \\
(0.004)\end{array}$ & $\begin{array}{l}-0.395^{* * *} \\
(0.059)\end{array}$ & $\begin{array}{l}-0.310^{* * *} \\
(0.046)\end{array}$ & $\begin{array}{l}-0.027 * * * \\
(0.005)\end{array}$ & $\begin{array}{l}0.014 * * * \\
(0.001)\end{array}$ \\
\hline GDP & $\begin{array}{l}0.011 * * \\
(0.003)\end{array}$ & $\begin{array}{l}-0.002 \\
(0.003)\end{array}$ & $\begin{array}{l}0.192 * * * \\
(0.042)\end{array}$ & $\begin{array}{l}0.098 * * \\
(0.038)\end{array}$ & $\begin{array}{l}-0.017 * * * \\
(0.004)\end{array}$ & $\begin{array}{l}0.006^{* * *} \\
(0.001)\end{array}$ \\
\hline Remoteness & $\begin{array}{l}-0.024 * \\
(0.010)\end{array}$ & $\begin{array}{l}0.012 \\
(0.007)\end{array}$ & $\begin{array}{l}-0.388^{*} \\
(0.156)\end{array}$ & $\begin{array}{l}-0.298^{* *} \\
(0.111)\end{array}$ & $\begin{array}{l}-0.005 \\
(0.009)\end{array}$ & $\begin{array}{l}0.004 \\
(0.002)\end{array}$ \\
\hline $\begin{array}{l}\text { Monetary } \\
\text { cost }\end{array}$ & $\begin{array}{l}-0.012 \\
(0.008)\end{array}$ & $\begin{array}{l}-0.003 \\
(0.007)\end{array}$ & $\begin{array}{l}-0.137 \\
(0.095)\end{array}$ & $\begin{array}{l}-0.078 \\
(0.087)\end{array}$ & $\begin{array}{l}-0.033^{* *} \\
(0.012)\end{array}$ & $(0.003)$ \\
\hline Time cost & $\begin{array}{l}-0.030 * * * \\
(0.007)\end{array}$ & $\begin{array}{l}0.021 * * * \\
(0.005)\end{array}$ & $\begin{array}{l}-0.375^{* * *} \\
(0.068)\end{array}$ & $\begin{array}{l}-0.390 * * * \\
(0.066)\end{array}$ & $\begin{array}{l}-0.007 \\
(0.008)\end{array}$ & $\begin{array}{l}0.002 \\
(0.003)\end{array}$ \\
\hline Size & $\begin{array}{l}-0.003 \\
(0.003)\end{array}$ & $\begin{array}{l}0.004 * \\
(0.002)\end{array}$ & $\begin{array}{l}-0.068 \\
(0.047)\end{array}$ & $\begin{array}{l}-0.034 \\
(0.034)\end{array}$ & $\begin{array}{l}-0.001 \\
(0.003)\end{array}$ & $\begin{array}{l}-0.000 \\
(0.001)\end{array}$ \\
\hline Population & $\begin{array}{l}0.012 * * \\
(0.004)\end{array}$ & $\begin{array}{l}-0.014 * * * \\
(0.003)\end{array}$ & $\begin{array}{l}0.120^{*} \\
(0.058)\end{array}$ & $\begin{array}{l}0.100 * \\
(0.051)\end{array}$ & $\begin{array}{l}0.034 * * * \\
(0.006)\end{array}$ & $\begin{array}{l}-0.007 * * * \\
(0.002)\end{array}$ \\
\hline $\begin{array}{l}\text { Firm pro- } \\
\text { ductivity }\end{array}$ & $0.016^{* * *}$ & $0.007 * * *$ & $0.066^{* * * *}$ & $0.066^{* * * *}$ & $0.020 * * *$ & $\begin{array}{l}-0.001 \\
(0.001)\end{array}$ \\
\hline Constant & $\begin{array}{l}2.186 \text { *** } \\
(0.066)\end{array}$ & $\begin{array}{l}1.405^{* * * *} \\
(0.060)\end{array}$ & $\begin{array}{l}-2.503 * * \\
(0.786)\end{array}$ & $\begin{array}{l}-1.236 \\
(0.691)\end{array}$ & $\begin{array}{l}1.859 * * * \\
(0.084)\end{array}$ & $\begin{array}{l}2.231 * * * \\
(0.028)\end{array}$ \\
\hline Observations & 302,104 & 302,104 & 283,256 & 286,608 & 302,018 & 302,104 \\
\hline Pseudo- $R^{2}$ & 0.036 & 0.019 & 0.180 & 0.142 & 0.194 & 0.068 \\
\hline Time FE & Yes & Yes & Yes & Yes & Yes & Yes \\
\hline Firm FE & Yes & Yes & Yes & Yes & Yes & Yes \\
\hline
\end{tabular}

Robust standard errors clustered at the destination country in parentheses. The PPML-routine results in more singletons that are dropped; thus, the number of observations along the various margins differs from the number of observations in the OLS analysis. As a robustness check, we have also estimated Table 5 with clusters at the firm level. This does not result in any differences in the sign or significance level of the covariates

$* * * p<0.01 ; * * p<0.05 ; * p<0.10$

at the firm level. The results are presented in Table 8 in "Appendix." This exercise does not result in any qualitative differences in the results. 


\section{Product characteristics and trade margins}

In this section, we investigate if the results differ across main product characteristics. Equation (3) is re-estimated for all proposed margins dividing the data into three groups based on the classification of Rauch (1999) of exports into differentiated goods, reference priced goods and goods traded on organized exchanges. Differentiated goods have a value share of $37 \%$, with the corresponding numbers for reference priced goods and goods traded on organized exchanges being $40 \%$ and $23 \%$. Results are presented group wise for the different groups of explanatory variables in Tables 5 and $6 . R^{2}$ and number of observations are reported for all regressions in Table 4.

From Table 5, one can see that there are clear differences between the groups. Rauch (1999) argues that the negative distance effect is stronger for reference priced goods than for the two other groups, and this is the case also here. The negative effect from distance on total export value for homogeneous goods is stronger than the effect from differentiated products. Exporters of reference priced goods are more negatively affected by increased distance both when it comes to the number of foreign trading partners and the number of exported products than exporters of other goods.

We find a positive effect from increased transportation cost (as measured by distance) on unit values for all three groups of products. The positive gradient between unit values and geographical distance found is in line with the Alchian and Allen (1964) effect of distant consumers demanding high-quality goods. For all types of products, high unit values are associated with large economies. The effect of distance on unit value and mean shipment weight is larger for differentiated products. This is supportive of a quality sorting effect on unit values allowed by differentiated products.

When it comes to the two newest elements of the extensive margin, the number of shipments and importers, we find mixed effects from the gravity variables among the three product groups. As distance increases, the number of shipments of differentiated products increases, while it is reduced for products sold on organized exchanges. The economic size of the destination market is positively associated with the number of shipments of reference priced product and negatively associated with shipments of differentiated products.

The effect from the gravity variables on the number of importers is similar across product groups. Distance and remoteness chokes off the number of connections, while increased economic size of the destination market boosts the number of importer connections.

The effect of time costs shown in Table 6 is stronger for differentiated goods than for homogeneous goods. Increased monetary costs have no significant effect on the total export value for any of the three product categories. Increases in time costs are negatively associated with the number of foreign trading partners for firms exporting differentiated and homogeneous goods. Increased per-shipment costs result in larger unit values for both differentiated and homogeneous goods, and this is in line with the findings in Hornok and Koren (2015). Increased internal transportation costs have a negative impact on export values of products sold on organized exchanges. For the population variable, the results for differentiated and homogeneous goods are line with Lawless (2010) when it comes to total export value. The overall effect from firm productivity is positive on export values in all three groups, and the effects are strongest 
Table 5 Margins and gravity variables

\begin{tabular}{|c|c|c|c|c|c|c|}
\hline & $\begin{array}{l}\text { (1) } \\
\text { Export value }\end{array}$ & $\begin{array}{l}(2) \\
\text { Mean \# } \\
\text { shipments } \\
\text { per } \\
\text { importer } \\
\text { per product }\end{array}$ & $\begin{array}{l}(3) \\
\# \text { of } \\
\text { importers }\end{array}$ & $\begin{array}{l}\text { (4) } \\
\text { \# products }\end{array}$ & $\begin{array}{l}(5) \\
\text { Mean } \\
\text { shipment } \\
\text { weight }\end{array}$ & $\begin{array}{l}(6) \\
\text { Mean uni } \\
\text { value }\end{array}$ \\
\hline \multicolumn{7}{|c|}{$\begin{array}{l}\text { Differentiated } \\
\text { products }\end{array}$} \\
\hline Distance & $\begin{array}{l}-0.259 * * * \\
(0.060)\end{array}$ & $\begin{array}{l}0.050 * * * \\
(0.016)\end{array}$ & $\begin{array}{l}-0.187 * * * \\
(0.035)\end{array}$ & $\begin{array}{l}-0.146^{* * * *} \\
(0.027)\end{array}$ & $\begin{array}{l}-0.141 * * * \\
(0.031)\end{array}$ & $\begin{array}{l}0.163 * * * \\
(0.016)\end{array}$ \\
\hline GDP & $\begin{array}{l}0.085^{*} \\
(0.045)\end{array}$ & $\begin{array}{l}-0.022 * \\
(0.013)\end{array}$ & $\begin{array}{l}0.087 * * * \\
(0.025)\end{array}$ & $\begin{array}{l}0.045 * * \\
(0.020)\end{array}$ & $\begin{array}{l}-0.085^{* * * *} \\
(0.025)\end{array}$ & $\begin{array}{l}0.060 \text { *** } \\
(0.020)\end{array}$ \\
\hline Remoteness & $\begin{array}{l}-0.199 * \\
(0.120)\end{array}$ & $\begin{array}{l}0.046 \\
(0.032)\end{array}$ & $\begin{array}{l}-0.135^{* *} \\
(0.069)\end{array}$ & $\begin{array}{l}-0.116^{* *} \\
(0.054)\end{array}$ & $\begin{array}{l}-0.024 \\
(0.055)\end{array}$ & $\begin{array}{l}0.029 \\
(0.032)\end{array}$ \\
\hline Obs & 258,607 & 258,607 & 258,607 & 258,607 & 258,607 & 258,607 \\
\hline$R^{2}$ & 0.398 & 0.330 & 0.367 & 0.328 & 0.654 & 0.727 \\
\hline \multicolumn{7}{|l|}{$\begin{array}{c}\text { Reference } \\
\text { priced } \\
\text { products }\end{array}$} \\
\hline Distance & $\begin{array}{l}-0.364 * * * \\
(0.049)\end{array}$ & $\begin{array}{l}0.015 \\
(0.015)\end{array}$ & $\begin{array}{l}-0.262 * * * \\
(0.030)\end{array}$ & $\begin{array}{l}-0.153 * * * \\
(0.019)\end{array}$ & $\begin{array}{l}-0.103 * * * \\
(0.025)\end{array}$ & $\begin{array}{l}0.139 * * * \\
(0.012)\end{array}$ \\
\hline GDP & $\begin{array}{l}0.203 * * * \\
(0.047)\end{array}$ & $\begin{array}{l}0.058 * * * \\
(0.015)\end{array}$ & $\begin{array}{l}0.121 * * * \\
(0.024)\end{array}$ & $\begin{array}{l}0.049 * * * \\
(0.017)\end{array}$ & $\begin{array}{l}-0.120 * * * \\
(0.032)\end{array}$ & $\begin{array}{l}0.095 * * * \\
(0.015)\end{array}$ \\
\hline Remoteness & $\begin{array}{l}-0.255^{* * *} \\
(0.088)\end{array}$ & $\begin{array}{l}0.027 \\
(0.034)\end{array}$ & $\begin{array}{l}-0.205^{* * *} \\
(0.056)\end{array}$ & $\begin{array}{l}-0.131 \text { *** } \\
(0.037)\end{array}$ & $\begin{array}{l}0.073 \\
(0.054)\end{array}$ & $\begin{array}{l}-0.019 \\
(0.029)\end{array}$ \\
\hline Obs & 68,760 & 68,760 & 68,760 & 68,760 & 68,760 & 68,760 \\
\hline$R^{2}$ & 0.535 & 0.379 & 0.392 & 0.375 & 0.733 & 0.790 \\
\hline $\begin{array}{c}\text { Organized } \\
\text { exchange }\end{array}$ & & & & & & \\
\hline Distance & $\begin{array}{l}-0.132 * * \\
(0.062)\end{array}$ & $\begin{array}{l}-0.048 * * \\
(0.024)\end{array}$ & $\begin{array}{l}-0.130 * * * \\
(0.033)\end{array}$ & $\begin{array}{l}-0.045^{* * * *} \\
(0.013)\end{array}$ & $\begin{array}{l}0.006 \\
(0.038)\end{array}$ & $\begin{array}{l}0.085^{* * *} \\
(0.018)\end{array}$ \\
\hline GDP & $\begin{array}{l}0.202 * * * \\
(0.069)\end{array}$ & $\begin{array}{l}0.013 \\
(0.028)\end{array}$ & $\begin{array}{l}0.128 * * * \\
(0.036)\end{array}$ & $\begin{array}{l}0.024 \\
(0.015)\end{array}$ & $\begin{array}{l}-0.030 \\
(0.045)\end{array}$ & $\begin{array}{l}0.068 * * * \\
(0.025)\end{array}$ \\
\hline Remoteness & $\begin{array}{l}-0.311^{* *} \\
(0.151)\end{array}$ & $\begin{array}{l}0.008 \\
(0.052)\end{array}$ & $\begin{array}{l}-0.236^{* *} \\
(0.105)\end{array}$ & $\begin{array}{l}-0.083^{* *} \\
(0.039)\end{array}$ & $\begin{array}{l}0.030 \\
(0.082)\end{array}$ & $\begin{array}{l}-0.030 \\
(0.043)\end{array}$ \\
\hline Obs & 21,468 & 21,468 & 21,468 & 21,468 & 21,468 & 21,468 \\
\hline$R^{2}$ & 0.639 & 0.473 & 0.374 & 0.366 & 0.809 & 0.806 \\
\hline
\end{tabular}

Robust standard errors clustered at the destination country in parentheses. All regressors from Eq. (4) included but not reported

$* * * p<0.01 ; * * p<0.05 ; * p<0.10$ 
Table 6 Margins, various trade costs and productivity

\begin{tabular}{|c|c|c|c|c|c|c|}
\hline & $\begin{array}{l}\text { (1) } \\
\text { Export value }\end{array}$ & $\begin{array}{l}(2) \\
\text { Mean \# } \\
\text { shipments } \\
\text { per } \\
\text { importer } \\
\text { per product }\end{array}$ & $\begin{array}{l}(3) \\
\# \text { of } \\
\text { importers }\end{array}$ & $\begin{array}{l}\text { (4) } \\
\text { \# products }\end{array}$ & $\begin{array}{l}(5) \\
\text { Mean } \\
\text { shipment } \\
\text { weight }\end{array}$ & $\begin{array}{l}(6) \\
\text { Mean unit } \\
\text { value }\end{array}$ \\
\hline \multicolumn{7}{|c|}{$\begin{array}{c}\text { Differentiated } \\
\text { products }\end{array}$} \\
\hline \multirow[t]{2}{*}{$\begin{array}{l}\text { Monetary } \\
\text { cost }\end{array}$} & -0.169 & -0.004 & -0.048 & -0.030 & $-0.218 * * *$ & $0.129 * * *$ \\
\hline & $(0.112)$ & $(0.031)$ & $(0.058)$ & $(0.047)$ & $(0.072)$ & $(0.040)$ \\
\hline Time cost & $\begin{array}{l}-0.375^{* * *} \\
(0.090)\end{array}$ & $\begin{array}{l}0.078 * * * \\
(0.020)\end{array}$ & $\begin{array}{l}-0.232 * * * \\
(0.046)\end{array}$ & $\begin{array}{l}-0.207 * * * \\
(0.038)\end{array}$ & $\begin{array}{l}-0.022 \\
(0.048)\end{array}$ & $\begin{array}{l}0.009 \\
(0.033)\end{array}$ \\
\hline Size & $\begin{array}{l}-0.013 \\
(0.033)\end{array}$ & $\begin{array}{l}0.021 * * \\
(0.009)\end{array}$ & $\begin{array}{l}-0.015 \\
(0.018)\end{array}$ & $\begin{array}{l}-0.010 \\
(0.015)\end{array}$ & $\begin{array}{l}-0.005 \\
(0.018)\end{array}$ & $\begin{array}{l}-0.003 \\
(0.011)\end{array}$ \\
\hline Population & $\begin{array}{l}0.152 * * * \\
(0.056)\end{array}$ & $\begin{array}{l}-0.043^{* * *} \\
(0.014)\end{array}$ & $\begin{array}{l}0.049 * \\
(0.029)\end{array}$ & $\begin{array}{l}0.045^{*} \\
(0.024)\end{array}$ & $\begin{array}{l}0.176 * * * \\
(0.033)\end{array}$ & $\begin{array}{l}-0.075^{* * *} \\
(0.020)\end{array}$ \\
\hline $\begin{array}{l}\text { Firm pro- } \\
\text { ductivity }\end{array}$ & $(0.012)$ & $(0.003)$ & $(0.005)$ & $(0.004)$ & $(0.012)$ & $\begin{array}{l}-0.015 \\
(0.009)\end{array}$ \\
\hline Constant & $\begin{array}{l}-0.169 \\
(0.112)\end{array}$ & $\begin{array}{l}-0.004 \\
(0.031)\end{array}$ & $\begin{array}{l}-0.048 \\
(0.058)\end{array}$ & $\begin{array}{l}-0.030 \\
(0.047)\end{array}$ & $\begin{array}{l}-0.218^{* * *} \\
(0.072)\end{array}$ & $\begin{array}{l}0.129 * * * \\
(0.040)\end{array}$ \\
\hline \multicolumn{7}{|l|}{$\begin{array}{l}\text { Reference } \\
\text { priced } \\
\text { products }\end{array}$} \\
\hline \multirow[t]{2}{*}{$\begin{array}{l}\text { Monetary } \\
\text { cost }\end{array}$} & -0.101 & $-0.061 * *$ & -0.050 & -0.017 & -0.121 & $0.147 * * *$ \\
\hline & $(0.093)$ & $(0.027)$ & $(0.043)$ & $(0.023)$ & $(0.076)$ & $(0.037)$ \\
\hline Time cost & $\begin{array}{l}-0.267 * * * \\
(0.079)\end{array}$ & $\begin{array}{l}-0.006 \\
(0.022)\end{array}$ & $\begin{array}{l}-0.122 * * \\
(0.047)\end{array}$ & $\begin{array}{l}-0.107 * * * \\
(0.028)\end{array}$ & $\begin{array}{l}-0.063 \\
(0.050)\end{array}$ & $\begin{array}{l}0.032 \\
(0.027)\end{array}$ \\
\hline Size & $\begin{array}{l}-0.026 \\
(0.029)\end{array}$ & $\begin{array}{l}0.010 \\
(0.009)\end{array}$ & $\begin{array}{l}-0.031 * * \\
(0.015)\end{array}$ & $\begin{array}{l}-0.011 \\
(0.010)\end{array}$ & $\begin{array}{l}0.019 \\
(0.015)\end{array}$ & $\begin{array}{l}-0.014 \\
(0.010)\end{array}$ \\
\hline Population & $\begin{array}{l}0.104 * \\
(0.057)\end{array}$ & $\begin{array}{l}-0.064 * * * \\
(0.015)\end{array}$ & $\begin{array}{l}0.042 \\
(0.027)\end{array}$ & $\begin{array}{l}0.017 \\
(0.017)\end{array}$ & $\begin{array}{l}0.199 * * * \\
(0.041)\end{array}$ & $\begin{array}{l}-0.089 * * * \\
(0.021)\end{array}$ \\
\hline $\begin{array}{l}\text { Firm pro- } \\
\text { ductivity }\end{array}$ & $(0.028)$ & $\begin{array}{l}0.088^{* * *} \\
(0.013)\end{array}$ & $(0.010)$ & $(0.008)$ & $\begin{array}{l}0.086^{* * * *} \\
(0.023)\end{array}$ & $\begin{array}{l}0.059 * * * \\
(0.017)\end{array}$ \\
\hline Constant & $\begin{array}{l}-0.101 \\
(0.093)\end{array}$ & $\begin{array}{l}-0.061 * * \\
(0.027)\end{array}$ & $\begin{array}{l}-0.050 \\
(0.043)\end{array}$ & $\begin{array}{l}-0.017 \\
(0.023)\end{array}$ & $\begin{array}{l}-0.121 \\
(0.076)\end{array}$ & $\begin{array}{l}0.147 * * * \\
(0.037)\end{array}$ \\
\hline \multicolumn{7}{|l|}{$\begin{array}{l}\text { Organized } \\
\text { exchange }\end{array}$} \\
\hline \multirow[t]{2}{*}{$\begin{array}{l}\text { Monetary } \\
\text { cost }\end{array}$} & -0.034 & -0.004 & -0.033 & 0.016 & -0.084 & 0.071 \\
\hline & $(0.144)$ & (0.059) & $(0.063)$ & $(0.025)$ & $(0.095)$ & $(0.053)$ \\
\hline
\end{tabular}


Table 6 continued

\begin{tabular}{|c|c|c|c|c|c|c|}
\hline & $\begin{array}{l}\text { (1) } \\
\text { Export value }\end{array}$ & $\begin{array}{l}(2) \\
\text { Mean \# } \\
\text { shipments } \\
\text { per } \\
\text { importer } \\
\text { per product }\end{array}$ & $\begin{array}{l}(3) \\
\# \text { of } \\
\text { importers }\end{array}$ & $\begin{array}{l}(4) \\
\text { \# products }\end{array}$ & $\begin{array}{l}(5) \\
\text { Mean } \\
\text { shipment } \\
\text { weight }\end{array}$ & $\begin{array}{l}(6) \\
\text { Mean unit } \\
\text { value }\end{array}$ \\
\hline Time cost & $\begin{array}{l}-0.015 \\
(0.119)\end{array}$ & $\begin{array}{l}-0.023 \\
(0.047)\end{array}$ & $\begin{array}{l}-0.088 \\
(0.066)\end{array}$ & $\begin{array}{l}-0.038 \\
(0.026)\end{array}$ & $\begin{array}{l}0.115 \\
(0.070)\end{array}$ & $\begin{array}{l}0.019 \\
(0.034)\end{array}$ \\
\hline Size & $\begin{array}{l}-0.106^{* * * *} \\
(0.032)\end{array}$ & $\begin{array}{l}-0.005 \\
(0.014)\end{array}$ & $\begin{array}{l}-0.068 * * * \\
(0.020)\end{array}$ & $\begin{array}{l}-0.013 \\
(0.008)\end{array}$ & $\begin{array}{l}-0.017 \\
(0.022)\end{array}$ & $\begin{array}{l}-0.004 \\
(0.012)\end{array}$ \\
\hline Population & $\begin{array}{l}0.066 \\
(0.086)\end{array}$ & $\begin{array}{l}-0.034 \\
(0.028)\end{array}$ & $\begin{array}{l}0.059 \\
(0.049)\end{array}$ & $\begin{array}{l}0.024 \\
(0.023)\end{array}$ & $\begin{array}{l}0.082 * \\
(0.045)\end{array}$ & $\begin{array}{l}-0.064 * * * \\
(0.022)\end{array}$ \\
\hline $\begin{array}{l}\text { Firm pro- } \\
\text { ductivity }\end{array}$ & $\begin{array}{l}0.179 * * * \\
(0.038)\end{array}$ & $\begin{array}{l}0.024 \\
(0.020)\end{array}$ & $\begin{array}{l}0.052 * * * \\
(0.018)\end{array}$ & $\begin{array}{l}0.025 * * * \\
(0.009)\end{array}$ & $\begin{array}{l}0.034 \\
(0.038)\end{array}$ & $\begin{array}{l}0.044 \\
(0.031)\end{array}$ \\
\hline Constant & $\begin{array}{l}-0.034 \\
(0.144)\end{array}$ & $\begin{array}{l}-0.004 \\
(0.059)\end{array}$ & $\begin{array}{l}-0.033 \\
(0.063)\end{array}$ & $\begin{array}{l}0.016 \\
(0.025)\end{array}$ & $\begin{array}{l}-0.084 \\
(0.095)\end{array}$ & $\begin{array}{l}0.071 \\
(0.053)\end{array}$ \\
\hline
\end{tabular}

Robust standard errors clustered at the destination country in parentheses. All regressors from Eq. (4) included but not reported

$* * * p<0.01 ; * * p<0.05 ; * p<0.10$

for homogenous products. The most productive firms trading in homogeneous products also receive a premium through larger unit values.

Shipment frequencies in homogeneous products are reduced as per-unit shipment costs increases and expand with firm productivity. For this product group, the number of importers is also negatively affected by increased per-unit shipment costs. The most productive exporters establish the largest networks in terms of the number of importers they connect to. As a robustness check, Table 5 and 6 are included with alternative clustering at the firm as Tables 9 and 10 in "Appendix." The qualitative differences are minor, but the firm clustering results in some improvements in the covariates significance for the intensive margin.

\section{Concluding remarks}

In recent years, more disaggregated data have facilitated more nuanced definitions of trade margins, as firms trade products at different frequencies (Bernard et al. 2014; Hornok and Koren 2015). There is also increasing recognition of the fact that the number of importing firms vary systematically with market-specific factors (Carballo et al. 2018; Bernard and Moxnes 2018). With access to data containing the number of trade partners in each export destination, we build on Bernard et al. (2014) and Hornok and Koren (2015) to include number of importing firms as a margin of trade.

Trade costs have always been important in explaining trade, and with firm data, these can be made more specific. Hence, in addition to the standard gravity measures distance 
and remoteness, we allow the margins to be influenced by degree of urbanization and country size as proposed by Lawless (2010) and shipment-specific costs as proposed by Hornok and Koren (2015). Starting with Bernard et al. (2007), a large literature has shown that larger and more productive firms trade more. We merge accounting data for exporting firms to also include these measures to explain trade margins.

Our empirical analysis of trade margins is conducted using Norwegian export data. Total export value is decomposed into five different elements; the mean number of shipments per trading partner per product traded, the number of trading partners (importers), the number of traded products, the mean shipment and the mean unit value.

Our results show that when the different trade determinants are combined, all factors are relevant in explaining the trade margins. The results on specific trade margins show that both the number of importers and shipping frequency to the importers makes up significant parts of the extensive margin of Norwegian exports. Since we disaggregated trade into more details than what is previously used in the literature, we are able to document that it is the most productive exporters that connect to the highest number of buyers. From the gravity literature, it is well known that increased distance to the destination market chokes off trade, and by estimating the nuanced parts of the trade margins, we document that the importer margin accounts for the largest part of this negative effect. As distance to the destination market increases, exporters reduce the size of their buyer network and trade more frequently in established networks. Further, we also show that the importer margin accounts for the largest part of the negative effect from per-unit shipment costs on aggregate trade. This shows the importance of the extensive margin in explaining cross-sectional differences in trade due to both the traditional gravity effects and trade costs.

The literature also provides several indications that trade margins vary with type of product. Categorizing the data by the well-known Rauch-classification into differentiated-, reference priced- and organized exchange products, this hypothesis is investigated. Not, surprisingly, the margins differ significantly by product group. In particular, Rauch's (1999) argument that the negative distance effect is stronger for reference priced goods than for the two other groups is supported. Moreover, while a positive gradient exists between unit values and geographical distance found is in line with the Alchian and Allen (1964) effect of distant buyers purchasing higher-quality goods, this vary by product group, and in particular, it is lower for products traded at exchanges.

Acknowledgements Financial support from the Norwegian research council (CT \# 233836) is acknowledged.

Funding Open Access funding provided by Norwegian Business School.

Open Access This article is licensed under a Creative Commons Attribution 4.0 International License, which permits use, sharing, adaptation, distribution and reproduction in any medium or format, as long as you give appropriate credit to the original author(s) and the source, provide a link to the Creative Commons licence, and indicate if changes were made. The images or other third party material in this article are included in the article's Creative Commons licence, unless indicated otherwise in a credit line to the material. If material is not included in the article's Creative Commons licence and your intended use is not permitted 
by statutory regulation or exceeds the permitted use, you will need to obtain permission directly from the copyright holder. To view a copy of this licence, visit http://creativecommons.org/licenses/by/4.0/.

\section{Appendix}

See Tables 7, 8, 9 and 10.

Table 7 Categories in the Norwegian Customs Tariff

\begin{tabular}{|c|c|}
\hline Chapter (category) & Description of contents \\
\hline 1. & Live animals; animal products \\
\hline 2. & Vegetable products \\
\hline 3. & $\begin{array}{l}\text { Animal or vegetable fats and oils and their cleavage products; prepared edible } \\
\text { fats; animal or vegetable waxes }\end{array}$ \\
\hline 4. & $\begin{array}{l}\text { Prepared foodstuffs; beverages, spirits and vinegar; tobacco and manufactured } \\
\text { tobacco substitutes }\end{array}$ \\
\hline 5. & Mineral products \\
\hline 6. & Products of the chemical or allied industries \\
\hline 7. & Plastics and articles thereof; rubber and articles thereof \\
\hline 8. & $\begin{array}{l}\text { Raw hides and skins, leather, furskins and articles thereof; saddlery and harness; } \\
\text { travel goods, handbags and similar containers; articles of animal gut (other than } \\
\text { silk-worm gut) }\end{array}$ \\
\hline 9. & $\begin{array}{l}\text { Wood and articles of wood; wood charcoal; cork and articles of cork; manufacture } \\
\text { of straw, of esparto or other plaiting materials; basketware and wickerwork }\end{array}$ \\
\hline 10. & $\begin{array}{l}\text { Pulp of wood or of other fibrous cellulosic material; recovered (waste and scrap) } \\
\text { paper or paperboard; paper and paperboard and articles thereof }\end{array}$ \\
\hline 11. & Textiles and textile articles \\
\hline 12. & $\begin{array}{l}\text { Footwear, headgear, umbrellas, sun umbrellas, walking-sticks, seat-sticks, whips, } \\
\text { riding-crops and parts thereof; prepared feathers and articles made therewith; } \\
\text { artificial flowers; articles of human hair }\end{array}$ \\
\hline 13. & $\begin{array}{l}\text { Articles of stone, plaster, cement, asbestos, mica or similar materials; ceramic } \\
\text { products; glass and glassware }\end{array}$ \\
\hline 14. & $\begin{array}{l}\text { Natural or cultured pearls, precious or semi-precious stones, precious metals, } \\
\text { metals clad with precious metal, and articles thereof; imitation jewelery; coin }\end{array}$ \\
\hline 15. & Base metals and articles of base metal \\
\hline 16. & $\begin{array}{l}\text { Machinery and mechanical appliances; electrical equipment; parts thereof; sound } \\
\text { recorders and reproducers, television image and sound recorders and } \\
\text { reproducers, and parts and accessories of such articles }\end{array}$ \\
\hline 17. & Vehicles, aircraft, vessels and associated transport equipment \\
\hline 18. & $\begin{array}{l}\text { Optical, photographic, cinematographic, measuring, checking, precision, medical } \\
\text { or surgical instruments and apparatus; clocks and watches; musical instruments; } \\
\text { parts and accessories thereof }\end{array}$ \\
\hline 19. & Arms and ammunition; parts and accessories thereof \\
\hline 20. & Miscellaneous manufactured articles \\
\hline 21. & Works of art, collectors' pieces and antiques \\
\hline
\end{tabular}


Table 8 Margin regressions, full data set

\begin{tabular}{|c|c|c|c|c|c|c|}
\hline & $\begin{array}{l}\text { (1) } \\
\text { Export value }\end{array}$ & $\begin{array}{l}(2) \\
\text { Mean \# } \\
\text { shipments } \\
\text { per } \\
\text { importer } \\
\text { per product }\end{array}$ & $\begin{array}{l}(3) \\
\# \text { of } \\
\text { importers }\end{array}$ & $\begin{array}{l}\text { (4) } \\
\text { \# products }\end{array}$ & $\begin{array}{l}(5) \\
\text { Mean } \\
\text { shipment } \\
\text { weight }\end{array}$ & $\begin{array}{l}(6) \\
\text { Mean unit } \\
\text { value }\end{array}$ \\
\hline Distance & $\begin{array}{l}-0.325^{* * *} \\
(0.013)\end{array}$ & $\begin{array}{l}0.055^{* * *} \\
(0.005)\end{array}$ & $\begin{array}{l}-0.226^{* * *} \\
(0.006)\end{array}$ & $\begin{array}{l}-0.179 * * * \\
(0.005)\end{array}$ & $\begin{array}{l}-0.142 * * * \\
(0.009)\end{array}$ & $\begin{array}{l}0.166^{* * *} \\
(0.006)\end{array}$ \\
\hline GDP & $\begin{array}{l}0.139 * * * \\
(0.017)\end{array}$ & $\begin{array}{l}-0.007 \\
(0.006)\end{array}$ & $\begin{array}{l}0.110 * * * \\
(0.009)\end{array}$ & $\begin{array}{l}0.057 * * * \\
(0.007)\end{array}$ & $\begin{array}{l}-0.087 * * * \\
(0.012)\end{array}$ & $\begin{array}{l}0.067 * * * \\
(0.008)\end{array}$ \\
\hline Remoteness & $\begin{array}{l}-0.290 * * * \\
(0.025)\end{array}$ & $\begin{array}{l}0.052^{* * * *} \\
(0.010)\end{array}$ & $\begin{array}{l}-0.187 * * * \\
(0.011)\end{array}$ & $\begin{array}{l}-0.161^{* * *} \\
(0.009)\end{array}$ & $\begin{array}{l}-0.034 * \\
(0.019)\end{array}$ & $\begin{array}{l}0.037 * * * \\
(0.013)\end{array}$ \\
\hline \multirow[t]{2}{*}{$\begin{array}{l}\text { Monetary } \\
\text { cost }\end{array}$} & $-0.142 * * *$ & -0.013 & $-0.044 * * *$ & $-0.024 * * *$ & $-0.190 * * *$ & $0.128 * * *$ \\
\hline & $(0.024)$ & $(0.009)$ & $(0.010)$ & $(0.008)$ & $(0.019)$ & $(0.011)$ \\
\hline Time cost & $\begin{array}{l}-0.375^{* * *} \\
(0.019)\end{array}$ & $\begin{array}{l}0.087 * * * \\
(0.008)\end{array}$ & $\begin{array}{l}-0.229 * * * \\
(0.009)\end{array}$ & $\begin{array}{l}-0.220^{* * *} \\
(0.008)\end{array}$ & $\begin{array}{l}-0.036^{* *} \\
(0.015)\end{array}$ & $\begin{array}{l}0.023 * * \\
(0.010)\end{array}$ \\
\hline Size & $\begin{array}{l}-0.030^{* * *} \\
(0.006)\end{array}$ & $\begin{array}{l}0.018^{* * * *} \\
(0.003)\end{array}$ & $\begin{array}{l}-0.026^{* * *} \\
(0.003)\end{array}$ & $\begin{array}{l}-0.015^{* * *} \\
(0.002)\end{array}$ & $\begin{array}{l}-0.004 \\
(0.005)\end{array}$ & $\begin{array}{l}-0.003 \\
(0.003)\end{array}$ \\
\hline Population & $\begin{array}{l}0.140 * * * \\
(0.013)\end{array}$ & $\begin{array}{l}-0.057 * * * \\
(0.005)\end{array}$ & $\begin{array}{l}0.050 * * * \\
(0.006)\end{array}$ & $\begin{array}{l}0.046 * * * \\
(0.005)\end{array}$ & $\begin{array}{l}0.182^{* * *} \\
(0.011)\end{array}$ & $\begin{array}{l}-0.082 * * * \\
(0.007)\end{array}$ \\
\hline $\begin{array}{l}\text { Firm pro- } \\
\text { ductivity }\end{array}$ & $0.199 * * *$ & $(0.007)$ & $(0.007)$ & $0.034 * * *$ & $0.110 * * *$ & $\begin{array}{l}-0.008 \\
(0.012)\end{array}$ \\
\hline Constant & $\begin{array}{l}8.128 * * * \\
(0.374)\end{array}$ & $\begin{array}{l}0.047 \\
(0.151)\end{array}$ & $\begin{array}{l}-0.731^{* * *} \\
(0.158)\end{array}$ & $\begin{array}{l}0.066 \\
(0.149)\end{array}$ & $\begin{array}{l}5.863 * * * \\
(0.308)\end{array}$ & $\begin{array}{l}2.900 * * * \\
(0.219)\end{array}$ \\
\hline Observations & 309,717 & 309,717 & 309,717 & 309,717 & 309,717 & 309,717 \\
\hline$R^{2}$ & 0.456 & 0.362 & 0.375 & 0.334 & 0.699 & 0.757 \\
\hline Time FE & Yes & Yes & Yes & Yes & Yes & Yes \\
\hline Firm FE & Yes & Yes & Yes & Yes & Yes & Yes \\
\hline
\end{tabular}

Alternative clustering: firm. Robust standard errors clustered at the firm in parentheses $* * * p<0.01 ; * * p<0.05 ; * p<0.10$ 
Table 9 Margins and gravity variables

\begin{tabular}{|c|c|c|c|c|c|c|}
\hline & $\begin{array}{l}(1) \\
\text { Export value }\end{array}$ & $\begin{array}{l}(2) \\
\text { Mean \# } \\
\text { shipments } \\
\text { per } \\
\text { importer } \\
\text { per product }\end{array}$ & $\begin{array}{l}(3) \\
\# \text { of } \\
\text { importers }\end{array}$ & $\begin{array}{l}\text { (4) } \\
\text { \# products }\end{array}$ & $\begin{array}{l}\text { (5) } \\
\text { Mean } \\
\text { shipment } \\
\text { weight }\end{array}$ & $\begin{array}{l}(6) \\
\text { Mean uni } \\
\text { value }\end{array}$ \\
\hline \multicolumn{7}{|l|}{$\begin{array}{c}\text { Differentiated } \\
\text { products }\end{array}$} \\
\hline Distance & $\begin{array}{l}-0.259 * * * \\
(0.012)\end{array}$ & $\begin{array}{l}0.050 * * * \\
(0.005)\end{array}$ & $\begin{array}{l}-0.187 * * * \\
(0.006)\end{array}$ & $\begin{array}{l}-0.146^{* * * *} \\
(0.004)\end{array}$ & $\begin{array}{l}-0.141 * * * \\
(0.009)\end{array}$ & $\begin{array}{l}0.163 * * * \\
(0.006)\end{array}$ \\
\hline GDP & $\begin{array}{l}0.085^{* * *} \\
(0.019)\end{array}$ & $\begin{array}{l}-0.022 * * * \\
(0.006)\end{array}$ & $\begin{array}{l}0.087 * * * \\
(0.009)\end{array}$ & $\begin{array}{l}0.045^{* * *} \\
(0.008)\end{array}$ & $\begin{array}{l}-0.085^{* * *} \\
(0.012)\end{array}$ & $\begin{array}{l}0.060 * * * \\
(0.008)\end{array}$ \\
\hline Remoteness & $\begin{array}{l}-0.199 * * * \\
(0.025)\end{array}$ & $\begin{array}{l}0.046^{* * * *} \\
(0.010)\end{array}$ & $\begin{array}{l}-0.135^{* * * *} \\
(0.011)\end{array}$ & $\begin{array}{l}-0.116^{* * * *} \\
(0.009)\end{array}$ & $\begin{array}{l}-0.024 \\
(0.021)\end{array}$ & $\begin{array}{l}0.029 * * \\
(0.014)\end{array}$ \\
\hline Obs & 258,607 & 258,607 & 258,607 & 258,607 & 258,607 & 258,607 \\
\hline$R^{2}$ & 0.398 & 0.330 & 0.367 & 0.328 & 0.654 & 0.727 \\
\hline \multicolumn{7}{|l|}{$\begin{array}{c}\text { Reference } \\
\text { priced } \\
\text { products }\end{array}$} \\
\hline Distance & $\begin{array}{l}-0.364 * * * \\
(0.035)\end{array}$ & $\begin{array}{l}0.015 \\
(0.013)\end{array}$ & $\begin{array}{l}-0.262^{* * *} \\
(0.016)\end{array}$ & $\begin{array}{l}-0.153^{* * *} \\
(0.009)\end{array}$ & $\begin{array}{l}-0.103 * * * \\
(0.022)\end{array}$ & $\begin{array}{l}0.139 * * * \\
(0.012)\end{array}$ \\
\hline GDP & $\begin{array}{l}0.203 * * * \\
(0.032)\end{array}$ & $\begin{array}{l}0.058 * * * \\
(0.014)\end{array}$ & $\begin{array}{l}0.121 * * * \\
(0.015)\end{array}$ & $\begin{array}{l}0.049 * * * \\
(0.008)\end{array}$ & $\begin{array}{l}-0.120 * * * \\
(0.022)\end{array}$ & $\begin{array}{l}0.095 * * * \\
(0.015)\end{array}$ \\
\hline Remoteness & $\begin{array}{l}-0.255^{* * *} \\
(0.055)\end{array}$ & $\begin{array}{l}0.027 \\
(0.028)\end{array}$ & $\begin{array}{l}-0.205^{* * * *} \\
(0.023)\end{array}$ & $\begin{array}{l}-0.131 \text { *** } \\
(0.015)\end{array}$ & $\begin{array}{l}0.073^{*} \\
(0.041)\end{array}$ & $\begin{array}{l}-0.019 \\
(0.027)\end{array}$ \\
\hline Obs & 68,760 & 68,760 & 68,760 & 68,760 & 68,760 & 68,760 \\
\hline$R^{2}$ & 0.535 & 0.379 & 0.392 & 0.375 & 0.733 & 0.790 \\
\hline $\begin{array}{l}\text { Organized } \\
\text { exchange }\end{array}$ & & & & & & \\
\hline Distance & $\begin{array}{l}-0.132 * * * \\
(0.044)\end{array}$ & $\begin{array}{l}-0.048 * * * \\
(0.019)\end{array}$ & $\begin{array}{l}-0.130 * * * \\
(0.019)\end{array}$ & $\begin{array}{l}-0.045^{* * * *} \\
(0.009)\end{array}$ & $\begin{array}{l}0.006 \\
(0.033)\end{array}$ & $\begin{array}{l}0.085^{* * *} \\
(0.021)\end{array}$ \\
\hline GDP & $\begin{array}{l}0.202^{* * * *} \\
(0.060)\end{array}$ & $\begin{array}{l}0.013 \\
(0.017)\end{array}$ & $\begin{array}{l}0.128 * * \\
(0.055)\end{array}$ & $\begin{array}{l}0.024 * * \\
(0.011)\end{array}$ & $\begin{array}{l}-0.030 \\
(0.032)\end{array}$ & $\begin{array}{l}0.068 * * \\
(0.029)\end{array}$ \\
\hline Remoteness & $\begin{array}{l}-0.311^{* * *} \\
(0.116)\end{array}$ & $\begin{array}{l}0.008 \\
(0.041)\end{array}$ & $\begin{array}{l}-0.236 * * * \\
(0.053)\end{array}$ & $\begin{array}{l}-0.083 * * * \\
(0.025)\end{array}$ & $\begin{array}{l}0.030 \\
(0.075)\end{array}$ & $\begin{array}{l}-0.030 \\
(0.043)\end{array}$ \\
\hline Obs & 21,468 & 21,468 & 21,468 & 21,468 & 21,468 & 21,468 \\
\hline$R^{2}$ & 0.639 & 0.473 & 0.374 & 0.366 & 0.809 & 0.806 \\
\hline
\end{tabular}

Alternative clustering: firm. Robust standard errors clustered at the firm in parentheses. All regressors from Eq. (4) included but not reported $* * * p<0.01 ; * * p<0.05 ; * p<0.10$ 
Table 10 Margins, various trade costs and productivity

\begin{tabular}{|c|c|c|c|c|c|c|}
\hline & $\begin{array}{l}\text { (1) } \\
\text { Export value }\end{array}$ & $\begin{array}{l}(2) \\
\text { Mean \# } \\
\text { shipments } \\
\text { per } \\
\text { importer } \\
\text { per product }\end{array}$ & $\begin{array}{l}(3) \\
\# \text { of } \\
\text { importers }\end{array}$ & $\begin{array}{l}\text { (4) } \\
\text { \# products }\end{array}$ & $\begin{array}{l}(5) \\
\text { Mean } \\
\text { shipment } \\
\text { weight }\end{array}$ & $\begin{array}{l}(6) \\
\text { Mean unit } \\
\text { value }\end{array}$ \\
\hline \multicolumn{7}{|c|}{$\begin{array}{l}\text { Differentiated } \\
\text { products }\end{array}$} \\
\hline \multirow[t]{2}{*}{$\begin{array}{l}\text { Monetary } \\
\text { cost }\end{array}$} & $-0.169 * * *$ & -0.004 & $-0.048 * * *$ & $-0.030 * * *$ & $-0.218 * * *$ & $0.129 * * *$ \\
\hline & $(0.025)$ & $(0.008)$ & $(0.011)$ & $(0.009)$ & $(0.020)$ & $(0.012)$ \\
\hline Time cost & $\begin{array}{l}-0.375^{* * *} \\
(0.020)\end{array}$ & $\begin{array}{l}0.078 * * * \\
(0.008)\end{array}$ & $\begin{array}{l}-0.232 * * * \\
(0.009)\end{array}$ & $\begin{array}{l}-0.207 * * * \\
(0.008)\end{array}$ & $\begin{array}{l}-0.022 \\
(0.016)\end{array}$ & $\begin{array}{l}0.009 \\
(0.011)\end{array}$ \\
\hline Size & $\begin{array}{l}-0.013 * * \\
(0.006)\end{array}$ & $\begin{array}{l}0.021 * * * \\
(0.003)\end{array}$ & $\begin{array}{l}-0.015^{* * * *} \\
(0.003)\end{array}$ & $\begin{array}{l}-0.010 * * * \\
(0.002)\end{array}$ & $\begin{array}{l}-0.005 \\
(0.005)\end{array}$ & $\begin{array}{l}-0.003 \\
(0.004)\end{array}$ \\
\hline Population & $\begin{array}{l}0.152 * * * \\
(0.014)\end{array}$ & $\begin{array}{l}-0.043 * * * \\
(0.005)\end{array}$ & $\begin{array}{l}0.049 * * * \\
(0.006)\end{array}$ & $\begin{array}{l}0.045 * * * \\
(0.005)\end{array}$ & $\begin{array}{l}0.176^{* * * *} \\
(0.011)\end{array}$ & $\begin{array}{l}-0.075^{* * * *} \\
(0.007)\end{array}$ \\
\hline $\begin{array}{l}\text { Firm pro- } \\
\text { ductivity }\end{array}$ & $(0.018)$ & $(0.006)$ & $(0.006)$ & $(0.006)$ & $(0.018)$ & $\begin{array}{l}-0.015 \\
(0.013)\end{array}$ \\
\hline Constant & $\begin{array}{l}9.253 * * * \\
(0.399)\end{array}$ & $\begin{array}{l}0.367 * * \\
(0.147)\end{array}$ & $\begin{array}{l}-0.494 * * * \\
(0.163)\end{array}$ & $\begin{array}{l}0.016 \\
(0.160)\end{array}$ & $\begin{array}{l}5.919 * * * \\
(0.319)\end{array}$ & $\begin{array}{l}3.465 * * * \\
(0.218)\end{array}$ \\
\hline \multicolumn{7}{|l|}{$\begin{array}{c}\text { Reference } \\
\text { priced } \\
\text { products }\end{array}$} \\
\hline \multirow[t]{2}{*}{$\begin{array}{l}\text { Monetary } \\
\text { cost }\end{array}$} & $-0.101 * *$ & $-0.061 * * *$ & $-0.050 * * *$ & -0.017 & $-0.121 * * *$ & $0.147 * * *$ \\
\hline & $(0.050)$ & $(0.022)$ & $(0.018)$ & $(0.012)$ & $(0.042)$ & $(0.022)$ \\
\hline Time cost & $\begin{array}{l}-0.267 * * * \\
(0.047)\end{array}$ & $\begin{array}{l}-0.006 \\
(0.020)\end{array}$ & $\begin{array}{l}-0.122 * * * \\
(0.019)\end{array}$ & $\begin{array}{l}-0.107 * * * \\
(0.013)\end{array}$ & $\begin{array}{l}-0.063^{*} \\
(0.034)\end{array}$ & $\begin{array}{l}0.032 \\
(0.020)\end{array}$ \\
\hline Size & $\begin{array}{l}-0.026 \\
(0.016)\end{array}$ & $\begin{array}{l}0.010 \\
(0.008)\end{array}$ & $\begin{array}{l}-0.031 * * * \\
(0.006)\end{array}$ & $\begin{array}{l}-0.011^{* * *} \\
(0.004)\end{array}$ & $\begin{array}{l}0.019 \\
(0.013)\end{array}$ & $\begin{array}{l}-0.014 * \\
(0.008)\end{array}$ \\
\hline Population & $\begin{array}{l}0.104 * * * \\
(0.033)\end{array}$ & $\begin{array}{l}-0.064 * * * \\
(0.014)\end{array}$ & $\begin{array}{l}0.042 * * * \\
(0.012)\end{array}$ & $\begin{array}{l}0.017 * * \\
(0.008)\end{array}$ & $\begin{array}{l}0.199 * * * \\
(0.025)\end{array}$ & $\begin{array}{l}-0.089 * * * \\
(0.015)\end{array}$ \\
\hline $\begin{array}{l}\text { Firm pro- } \\
\text { ductivity }\end{array}$ & $\begin{array}{l}0.289 * * * \\
(0.037)\end{array}$ & $0.088 * * *$ & $0.042 * *$ & 0.015 & $0.086^{* *}$ & $\begin{array}{l}0.059 * * \\
(0.023)\end{array}$ \\
\hline Constant & $\begin{array}{l}5.750 * * * \\
(0.761)\end{array}$ & $\begin{array}{l}-1.108^{* * *} \\
(0.389)\end{array}$ & $\begin{array}{l}-0.905^{* *} \\
(0.369)\end{array}$ & $\begin{array}{l}0.267 \\
(0.242)\end{array}$ & $\begin{array}{l}7.325^{* * * *} \\
(0.645)\end{array}$ & $\begin{array}{l}0.172 \\
(0.441)\end{array}$ \\
\hline $\begin{array}{l}\text { Organized } \\
\text { exchange }\end{array}$ & & & & & & \\
\hline
\end{tabular}


Table 10 continued

\begin{tabular}{|c|c|c|c|c|c|c|}
\hline & $\begin{array}{l}\text { (1) } \\
\text { Export value }\end{array}$ & $\begin{array}{l}(2) \\
\text { Mean \# } \\
\text { shipments } \\
\text { per } \\
\text { importer } \\
\text { per product }\end{array}$ & $\begin{array}{l}\text { (3) } \\
\text { \# of } \\
\text { importers }\end{array}$ & $\begin{array}{l}(4) \\
\text { \# products }\end{array}$ & $\begin{array}{l}\text { (5) } \\
\text { Mean } \\
\text { shipment } \\
\text { weight }\end{array}$ & $\begin{array}{l}(6) \\
\text { Mean unit } \\
\text { value }\end{array}$ \\
\hline \multirow[t]{2}{*}{$\begin{array}{l}\text { Monetary } \\
\text { cost }\end{array}$} & -0.034 & -0.004 & -0.033 & 0.016 & -0.084 & 0.071 \\
\hline & $(0.090)$ & $(0.037)$ & $(0.048)$ & $(0.015)$ & $(0.067)$ & $(0.045)$ \\
\hline Time cost & $\begin{array}{l}-0.015 \\
(0.075)\end{array}$ & $\begin{array}{l}-0.023 \\
(0.033)\end{array}$ & $\begin{array}{l}-0.088^{* *} \\
(0.041)\end{array}$ & $\begin{array}{l}-0.038 * * \\
(0.018)\end{array}$ & $\begin{array}{l}0.115^{* *} \\
(0.051)\end{array}$ & $\begin{array}{l}0.019 \\
(0.035)\end{array}$ \\
\hline Size & $\begin{array}{l}-0.106^{* * *} \\
(0.026)\end{array}$ & $\begin{array}{l}-0.005 \\
(0.012)\end{array}$ & $\begin{array}{l}-0.068 * * * \\
(0.010)\end{array}$ & $\begin{array}{l}-0.013^{* *} \\
(0.005)\end{array}$ & $\begin{array}{l}-0.017 \\
(0.019)\end{array}$ & $\begin{array}{l}-0.004 \\
(0.013)\end{array}$ \\
\hline Population & $\begin{array}{l}0.066 \\
(0.046)\end{array}$ & $\begin{array}{l}-0.034 * * \\
(0.016)\end{array}$ & $\begin{array}{l}0.059 \\
(0.037)\end{array}$ & $\begin{array}{l}0.024 * * \\
(0.011)\end{array}$ & $\begin{array}{l}0.082 * * * \\
(0.031)\end{array}$ & $\begin{array}{l}-0.064^{* *} \\
(0.027)\end{array}$ \\
\hline $\begin{array}{l}\text { Firm pro- } \\
\text { ductivity }\end{array}$ & $\begin{array}{l}0.179 * * * \\
(0.043)\end{array}$ & $\begin{array}{l}0.024 \\
(0.023)\end{array}$ & $\begin{array}{l}0.052 * * * \\
(0.017)\end{array}$ & $\begin{array}{l}0.025 * * \\
(0.011)\end{array}$ & $\begin{array}{l}0.034 \\
(0.046)\end{array}$ & $\begin{array}{l}0.044 \\
(0.037)\end{array}$ \\
\hline Constant & $\begin{array}{l}5.736^{* * * *} \\
(1.210)\end{array}$ & $\begin{array}{l}0.786 \\
(0.508)\end{array}$ & $\begin{array}{l}-2.318^{* * *} \\
(0.752)\end{array}$ & $\begin{array}{l}-0.712^{* * *} \\
(0.245)\end{array}$ & $\begin{array}{l}5.298 * * * \\
(0.962)\end{array}$ & $\begin{array}{l}2.681 * * * \\
(0.770)\end{array}$ \\
\hline
\end{tabular}

Alternative clustering: firm. Robust standard errors clustered at the firm in parentheses. All regressors from Eq. (4) included but not reported

$* * * p<0.01 ; * * p<0.05 ; * p<0.10$

\section{References}

Alchian AA, Allen WR. Univ Econ Belmont Calif.: Wadsworth. 1964.

Anderson JE, Van Wincoop E. Gravity with gravitas: a solution to the border puzzle. Am Econ Rev. 2003;93(1):170-92.

Arkolakis C, Demidova S, Klenow PJ, Rodriguez-Clare A. Endogenous variety and the gains from trade. Am Econ Rev. 2008;98(2):444-50.

Bernard AB, Moxnes A. Networks and trade. Annu Rev Econ. 2018;10:65-85.

Bernard AB, Jensen JB, Lawrence RZ. Exporters, jobs, and wages in US manufacturing: 1976-1987. Brook Pap Econ Act Microecon. 1995;1995:67-119.

Bernard AB, Jensen JB, Redding SJ, Schott PK. Firms in international trade. J Econ Perspect. 2007;21(3):105-30.

Bernard AB, Jensen JB, Schott PK. Importers, exporters and multinationals: a portrait of firms in the US that trade goods. In: Producer dynamics: new evidence from micro data. University of Chicago Press; 2009. p. 513-52.

Bernard AB, Redding SJ, Schott PK. Multiproduct firms and trade liberalization. Q J Econ. 2011;126(3):1271-318.

Bernard AB, Jensen JB, Redding SJ, Schott PK. The empirics of firm heterogeneity and international trade. Annu Rev Econ. 2012;4(1):283-313.

Bernard AB, Van Beveren I, Vandenbussche H. Multi-product exporters and the margins of trade. Jpn Econ Rev. 2014;65(2):142-57.

Bernard AB, Moxnes A, Ulltveit-Moe KH. Two-sided heterogeneity and trade. Rev Econ Stat. 2018;100(3):424-39.

Besedeš T, Prusa TJ. The role of extensive and intensive margins and export growth. J Dev Econ. 2011;96(2):371-9. 
Carballo J, Ottaviano GI, Martincus CV. The buyer margins of firms' exports. J Int Econ. 2018;112:33-49. Chaney T. The network structure of international trade. Am Econ Rev. 2014;104(11):3600-34.

Eaton J, Kortum S, Kramarz F. Dissecting trade: firms, industries, and export destinations. Am Econ Rev. 2004;94(2):150-4.

Feenstra RC, Romalis J. International prices and endogenous quality. Q J Econ. 2014;129(2):477-527.

Geishecker I, Schröder PJ, Sørensen A. One-off export events. Can J Econ. 2019;52(1):93-131.

Görg H, Halpern L, Muraközy B. Why do within-firm-product export prices differ across markets? Evidence from Hungary. World Econ. 2017;40(6):1233-46.

Hallak JC, Levinsohn J. Fooling ourselves: evaluating the globalization and growth debate (No. w10244). National Bureau of Economic Research. 2004.

Head K, Mayer T. Gravity equations: workhorse, toolkit, and cookbook, Ch. 3 in Handbook of Int Econ, Gopinath G, Helpman E, Rogoff K,editors, vol. 4, p. 131-95. 2014.

Hillberry R, Hummels D. Trade responses to geographic frictions: a decomposition using micro-data. Eur Econ Rev. 2008;52(3):527-50.

Hornok C, Koren M. Per-shipment costs and the lumpiness of international trade. Rev Econ Stat. 2015;97(2):525-30.

Johnson RC. Trade and prices with heterogeneous firms. J Int Econ. 2012;86(1):43-56.

Lawless M. Deconstructing gravity: trade costs and extensive and intensive margins. Can J Econ. 2010;43(4):1149-72.

Manova K, Zhang Z. Export prices across firms and destinations. Q J Econ. 2012;127(1):379-436.

Mayer T, Ottaviano GI. The happy few: the internationalisation of European firms. Intereconomics. 2008;43(3):135-48.

Melitz MJ. The impact of trade on intra-industry reallocations and aggregate industry productivity. Econometrica. 2003;71(6):1695-725.

Melitz MJ, Ottaviano GI. Market size, trade, and productivity. Rev Econ Stud. 2008;75(1):295-316.

Monarch R. 'It's Not You, It's Me': breakups in US-China trade relationships. US Census Bureau Center for Economic Studies paper no. CES-WP-14-08. 2014.

Rauch JE. Networks versus markets in international trade. J Int Econ. 1999;48(1):7-35.

Rauch JE, Trindade V. Ethnic Chinese networks in international trade. Rev Econ Stat. 2002;84(1):116-30. Silva JS, Tenreyro S. The log of gravity. Rev Econ Stat. 2006;88(4):641-58.

Publisher's Note Springer Nature remains neutral with regard to jurisdictional claims in published maps and institutional affiliations. 